九州大学学術情報リポジトリ

Kyushu University Institutional Repository

\title{
Biometry of Growth and Food Habits of Young of the Eastern Great White Egret, Egretta alba modesta, in Korea
}

Min, Byung Yoon

Zoological Laboratory, Faculty of Agriculture, Kyushu University

Honda, Katsuhisa

Department of Environment Conservation, Ehime University

Shiraishi, Satoshi

Zoological Laboratory, Faculty of Agriculture, Kyushu University

Tatsukawa, Ryo

Department of Environment Conservation, Ehime University

https://doi.org/10.5109/23792

出版情報：九州大学大学院農学研究院紀要. 29 (1)，pp.23-33，1984-09. Kyushu University バージョン：

権利関係 : 


\title{
Biometry of Growth and Food Habits of Young of the Eastern Great White Egret, Egretta alba modesta, in Korea
}

\author{
Byung Yoon Min, Katsuhisa Honda*, Satoshi Shiraishi \\ and Ryo Tatsukawa* \\ Zoological Laboratory, Faculty of Agriculture, \\ Kyushu University 46-06, Fukuoka 812 \\ (Received May 18, 1984)
}

\begin{abstract}
As a basic study on biological concentration of organochlorine compounds and heavy metals in the Eastern Great White Egret, Egretta alba modesta, the present investigation was carried out to examine the biometry of growth and food of young during the period from the inward (April) to outward (August) migration in Korea. In the chicks, the body weight, whole body lipid and moisture content and relation of tissue and organ weights to the body weight changed with growth, especially with flapping and flying activity. In the adults, body weight, whole body lipid and moisture content fluctuated widely owing to migration and breeding; the relationship of tissue and organ weights to the body weight was nearly constant through the period. The chicks fed mainly on loaches in addition to frogs and insects; the size of the loaches eaten by the chicks increased as they grew, indicating that the more the chicks grew, the larger fishes they selected.
\end{abstract}

\section{INTRODUCTION}

The Eastern Great White Egret, Egretta alba modesta, migrates for breeding to Korea, China and Japan late in March or early in April, and returns to the Philippines, Indonesia and Malaysia for wintering late in September or early in October. Little is known of the breeding ecology of the egret during the period from inward to outward migration in Korea, although there have been several studies on parts of the life history (Pratt, 1970; McClure, 1974; Tomlinson, 1976; Burger, 1978; Hancock and Elliott, 1978; Low and Mansell, 1983).

Recently, the egret in Korea is greatly reduced in numbers (Won, 1975; Seong, 1979). This is mainly due to destruction of the habitat by industrialization after the Korean War in 1950-1953 and to a direct or indirect disturbance by people, but the pollution by pesticides such as DDT and BHC (HCH) also seems to be closely related to the decline of this species. The absorption or accumulation level of these pollutants by or in animals varies with their ecological and physiological status. For example, it is well known that these pollutants transfer from the mother to her fetus or baby through preg.

* Department of Environment Conservation, Ehime University, Tarumi 3-5-7, Matsuyama 790. 
nancy or lactation and accumulate with growth in the Striped Dolphin, Stenella coeruleoalba (Tanabe et al., 1981, 1982; Honda et al., 1982, 1983). The bioconcentration level of the pollutants appears to differ according to tissues and organs. Furthermore, the burdens of the pollutants in animal bodies are strongly affected by their food habit. For example, higher pesticide residues were detected in tissues and organs of herons than in any other piscivorous birds (Prestt, 1969; Faber et al., 1972; Koeman et al., 1972; van der Molen et al., 1982).

As a basic study on biological concentration of organochlorine compounds and heavy metals in the egret, we investigated changes in body weight, whole body lipid and moisture content, and in relationship of tissue and organ weights to the body weight according to growth, and foods through which organochlorine compounds and heavy metals are accumulated in the body.

\section{STUDY AREA AND METHODS}

Field examinations of the egret were carried out at the breeding site (1.2 ha) on a hill near a small village $2 \mathrm{~km}$ distant southward from the Cheonan City, Chungcheongnamdo, central part of Korea. Three adult egrets were captured every month during the period from April to August, and 3 chicks at time 1st, 12th, 24th, 35th, 45th and 55th day after hatching, respectively. The specimens were immediately frozen at $-20^{\circ} \mathrm{C}$ until measurement and autopsy. After weighing, each specimen was dissected, and then the whole bones, skin, liver, pectoral muscle, other muscles, feathers and the others were separately weighed. All of the tissues or organs of each bird were homogenized; with respect to a part of the homogenized substance, lipids were extracted with ether in a Soxhlet apparatus, or moisture content was measured by a drying method (dried overnight in an $80^{\circ} \mathrm{C}$ oven); then the whole body lipid and moisture content were estimated.

Furthermore, the food intake and the kinds of prey animals in 5 chicks were examined by the collar method during the period from 1 June to 13 July, 1981. Of the 5 chicks, 3 were examined 4 times every 3 hours from $6: 00$ to $18: 00$ o'clock, and 2 once per the above 12 hours on every third day. Hunting (wading and waiting) by the adults was watched from $10: 00$ to $11: 00$ o'clock during the 20 days from 1 June to 8 July, excepting rainy days, with the naked eyes or a binocular (Nikon, 9 x30).

\section{RESULTS}

\section{Changes in body weight and food intake with growth in the chicks under natural population (Fig. 1)}

Nestlings began to get on their feet the 12th day after hatching and stood firmly 2 to 3 days later. The earliest flapping took place at the 30th day, and the first flight of 10 to 50 meters' distance was observed at the 40th day. They could fly more than $200 \mathrm{~m}$ at the 45th day and were fully fledged at the 
50th day. The chicks put on body weight rapidly or gradually until the 37th day, when they reached a maximum of $604 \mathrm{~g}$ on the average. Afterward, the chicks lost weight until the 46th day, but the weight increased again up to the 55th day corresponding to the fledging time.

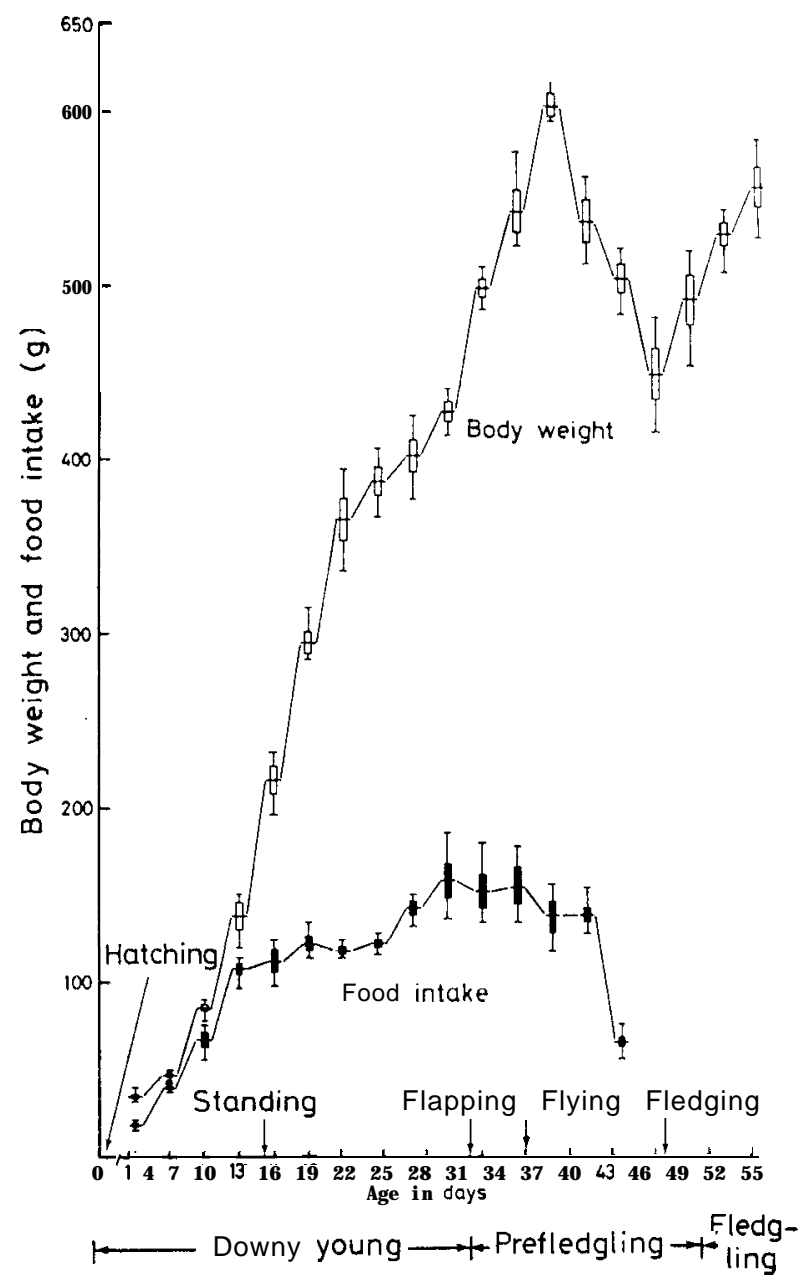

Fig. 1. Changes in body weight and food intake in the chicks of Egretta alba modesta. The vertical line, horizontal line and block indicate the range, mean and standard error, respectively.

The food intake of the chicks was an average of $15 \mathrm{~g}$ (43 $9 \%$ of the body weight) the 1st day after hatching, and increased rapidly up to not less than $78 \%$ of the body weight by the 10th day. Although it increased slightly until the 34th day, the rate to the body weight declined to $28-52 \%$. At the $43 \mathrm{rd}$ day, both the food intake (65 $\mathrm{g}$ on the average) and the rate to the body weight (13\% on the average) dropped rapidly. 
2. Changes in body weight, whole body lipid and moisture content in the chicks and adults (Fig. 2)

The body weight of the chicks averaged $785 \mathrm{~g}$ at the 70th day after hatching, approached that of the adults soon after. The whole body lipid content, averaging $4.7 \%$ at the 1 st day, lowered until the 24th day, afterward heightened by the 35 th day, then dropped suddenly at the 45th day, and was followed by a gradual increase with growth. The whole body moisture con-


Fig. 2. Changes in body weight, whole body lipid and moisture content in the chicken and adult egrets. $\bigcirc-\bigcirc$, body weight; - - lipid content; $\triangle-\triangle$, moisture content. 
tent, averaging $80.4 \%$ at the 1st clay, declined to about $72.6 \%$, approximating the adult content in April.

In the adults, the mean body weight increased rapidly in April and became heaviest $(1,079 \mathrm{~g})$ in May; it abruptly decreased in June, after which there was a secondary increase. The whole body lipid content was highest in May, and showed much the same tendency as in the body weight. The whole body moisture content was highest in April, lowered until July, and heightened again in August.

3. Changes in relationship of tissue and organ weights to body weight according to growth (Fig. 3)

Tissue and organ weights relative to body weight in the chicks changed remarkably with age in days. Weights of the whole bones and pectoral muscle increased as the chicks grew. Other muscles, liver and skin, and feathers reached the highest values at the 12 th and 35 th day, respectively, but a declining tendency was shown in all the tissues thereafter. On the other hand, the relationship of the other tissues, consisting mainly of the viscera, to body weight declined with age. In the adults, however, each relationship was nearly constant through the period examined.

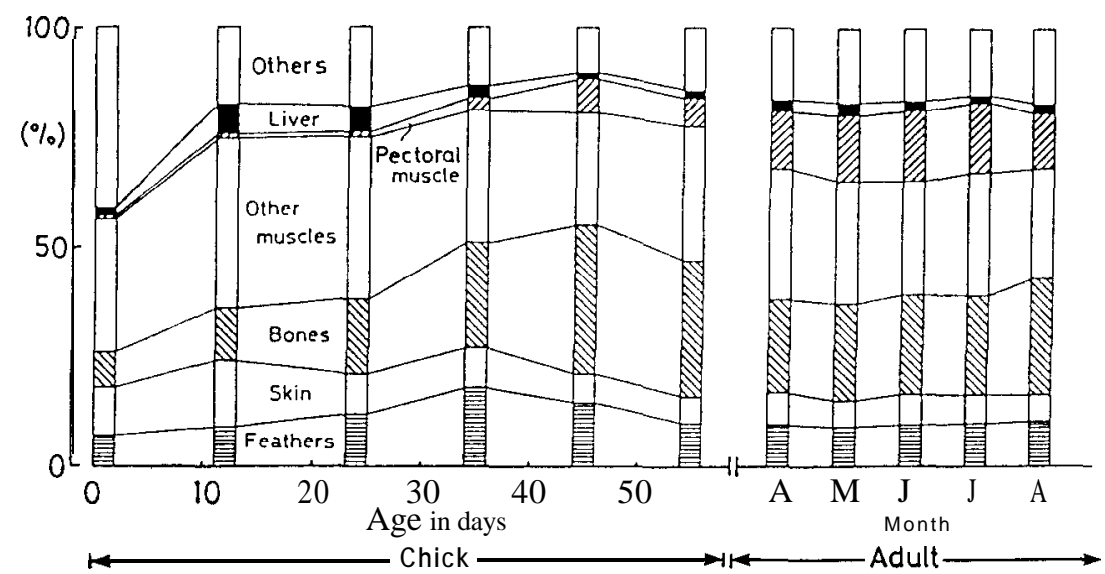

Fig. 3. Changes in relationship of tissue and organ weights to the body weight in the chicken and adult egrets.

Table 1. Occurrence frequency/hr of hunting by the adults of Egretta alba modesta.




Table 2. Prey animals obtained by the collar method from the egret chicks.

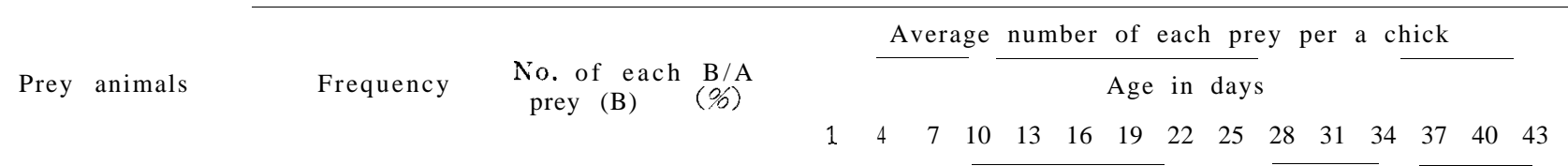

\author{
Osteichthyes \\ Misgurnus anguillicaudatus \\ Misgurnus mizolepis \\ Carassius auratus \\ Aphyocypris chinensis \\ Other small fishes \\ Total (A) \\ Amphibia \\ Rana sp. (Adult) \\ Rana sp. (Tadpole) \\ Total (A) \\ Insecta \\ Coleoptera (Larva) \\ Nepidae (Larva) \\ Libellulidae (Imagoj \\ Libellulidae (Larva) \\ Total (A) \\ Sum total
}

15

14

5

7

12

4
3
1
5
13
83

170

77

24

17

$295(62.0 \%) 100.0$

$\begin{array}{llllllllllllllll}57.6 & 8 & 18 & 9 & 19 & 19 & 15 & 18 & 12 & 9 & 8 & 12 & 8 & 6 & 6 & 3\end{array}$

$\begin{array}{lllllllllllllll}26.1 & 2 & 3 & 5 & 7 & 410 & 6 & 3 & 5 & 9 & 5 & 8 & 5 & 3 & 2\end{array}$

$\begin{array}{llllllllllllllll}8.1 & 1 & 1 & 2 & 1 & 2 & 1 & 1 & 2 & 1 & 2 & - & 14 & 4 & 1\end{array}$

$\begin{array}{llllllllllllllll}5.8 & 1 & 2 & 2 & 3 & 1 & 2 & 3 & 2 & -1 & - & - & - & -\end{array}$

$2.4--1-1--31-1-\ldots$

$\begin{array}{llllllllllllllll}- & - & 1 & & & & & & & & & & & & & \end{array}$

$15 \quad 17.0$

$73-83.0$

$88(18.5 \%) 100.0$

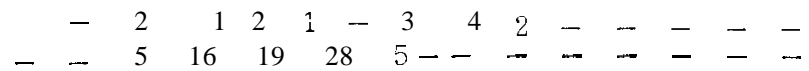

- $\quad 71721295342 \ldots-\ldots$

$\begin{array}{lrllllllllllllllll}10 & 10.7 & & - & 3 & 4 & 2 & 1 & - & - & - & - & - & - & - & - & - \\ 4 & 4.3 & & - & 2 & 1 & 1 & - & - & - & - & - & - & - & - & - & - \\ 1 & 1.1 & - & - & - & 1 & - & - & - & - & - & - & - & - & - & - & - \\ 78 & 83.9 & - & - & 3 & 6 & 27 & 8 & 5 & 2 & - & - & - & - & - & - & - & - \\ 93(19.596) & 100.0 & & - & 4 & 3 & 33 & 1 & 6 & 2 & - & - & - & - & - & - & - & - \\ 476 & 12 & 24 & 67 & 80 & 59 & 63 & 35 & 25 & 20 & 22 & 18 & 17 & 15 & 13 & 6\end{array}$



$-4$ 


\section{Food habit of the chicks}

The adults hunted frequently in paddy fields but rarely along shores and in fresh water marshes. Movements on the hunting area could be divided into two categories, i. e. wading and waiting methods, and the former was used 3-4 times more than the latter (Table 1).

The chicks were fed with animal prey such as fishes, frogs and insects by their parents (Table 2). They consumed fish everyday up to the 43rd day after hatching, but took in frogs and insects during the period from the 7 th each to the 28th and 12th day. Of the prey animals, fishes were most numer-

Table 3. Body length and weight of prey animals obtained by the collar method from the egret chicks.

\begin{tabular}{|c|c|c|c|c|c|}
\hline \multirow{2}{*}{ Prey animals } & \multirow{2}{*}{$\mathrm{N}$} & \multicolumn{2}{|c|}{ Length $(\mathrm{mm})$} & \multicolumn{2}{|c|}{ Weight $(g)$} \\
\hline & & Range & MI-S.E. & Range & $\mathrm{M} \pm \mathrm{S} . \mathrm{E}$. \\
\hline \multicolumn{6}{|l|}{ Osteichthyes } \\
\hline $\begin{array}{l}\text { Misgurnus anguillicaudatus } \\
\text { M. mizolepis } \\
\text { Carassius auratus } \\
\text { Aphyocypris chinensis } \\
\text { Other small fishes }\end{array}$ & $\begin{array}{r}170 \\
77 \\
24 \\
17 \\
7\end{array}$ & $\begin{array}{l}24.9-129.3 \\
25.1-116.7 \\
48.1-75.2 \\
47.9-61.8 \\
31.5-47.3\end{array}$ & $\begin{array}{l}83.92 \pm \mathbf{1 . 6 9} \\
81.33 \pm 2.42 \\
59.80 \pm 1.57 \\
54.02 \pm 1.06 \\
40.74 \pm 2.07\end{array}$ & $\begin{array}{l}0.2-12.6 \\
0.3-10.2 \\
5.9-9.8 \\
3.9-7.5 \\
1.9-3.3\end{array}$ & $\begin{array}{l}5.30 \pm 0.27 \\
5.45 \pm 0.36 \\
8.11 \pm 0.24 \\
5.91 \text { f0.26 } \\
2.71 \text { to. } 19\end{array}$ \\
\hline \multicolumn{6}{|l|}{ Amphibia } \\
\hline $\begin{array}{l}\text { Rana } \text { sp. } \quad \text { (Adult) } \\
\text { Rana } \text { sp. (Tadpole) }\end{array}$ & $\begin{array}{l}15 \\
73\end{array}$ & $\begin{array}{l}43.6-47.4 \\
26.4-37.2\end{array}$ & $\begin{array}{l}45.45 \pm 0.30 \\
32.73 \pm 0.33\end{array}$ & $\begin{array}{l}4.2-5.7 \\
0.3-1.6\end{array}$ & $\begin{array}{l}4.88 \pm 0.12 \\
0.95 \mathrm{t} 0.04\end{array}$ \\
\hline \multicolumn{6}{|l|}{ Insecta } \\
\hline $\begin{array}{l}\text { Coleoptera (Larva) } \\
\text { Nepidae (Larva) } \\
\text { Libellulidae (Imago) } \\
\text { Libellulidae (Larva) }\end{array}$ & $\begin{array}{r}10 \\
4 \\
1 \\
78\end{array}$ & $\begin{array}{l}33.9-46.1 \\
47.7-49.1 \\
49.8 \\
14.2-25.3\end{array}$ & $\begin{array}{l}11.47 \pm 1.30 \\
48.2010 .31 \\
20.36 \pm 0.32\end{array}$ & $\begin{array}{l}0.3-0.7 \\
0.3-0.8 \\
0.4 \\
0.1-0.4\end{array}$ & $\begin{array}{l}0.50 \pm 0.05 \\
0.60 \pm 0.11 \\
0.32 \pm 0.01\end{array}$ \\
\hline
\end{tabular}

Table 4. Changes in number, body length and weight of the loaches (Misgurnus anguillicaudatus and M. mizolepis) preyed by the egret chicks according to their age in days.

\begin{tabular}{|c|c|c|c|c|c|}
\hline \multirow{2}{*}{ Age in days } & \multirow{2}{*}{$\mathrm{N}$} & \multicolumn{2}{|c|}{ Length $(\mathrm{mm})$} & \multicolumn{2}{|c|}{ Weight (g) } \\
\hline & & Range & $\mathrm{M} \pm \mathrm{S} . \mathrm{E}$. & Range & $\mathrm{M} \pm \mathrm{S} . \mathrm{E}$ \\
\hline & 10 & $24.9-49.1$ & 41.07-t-2.19 & $0.3-1.5$ & $0.95 \pm 0.12$ \\
\hline 7 & $\begin{array}{l}21 \\
14\end{array}$ & $25.1-58.9$ & $52.98 \pm 1.61$ & $0.2-2.2$ & $1.41 \pm 0.11$ \\
\hline 10 & 23 & $32.44 .7-3-81.474 .2$ & $58.18 \pm 2.69 .1511 .17971$ & $0.7-1.8-4.33 .4$ & $2.06+0.232 .70+0.13$ \\
\hline 13 & 25 & $44.58 .3-1-89.383 .7$ & $79.53 \pm 1.9272 .8312 .12$ & 2.1.2-5-5.4.97 & $3.60 \pm 0.202 .93 \pm 0.20$ \\
\hline $\begin{array}{l}16 \\
19\end{array}$ & 24 & $70.7-88.0$ & $81.82+1.02$ & $35-53$ & 4.4710 .10 \\
\hline 22 & 15 & $77.3-93.2$ & $88.49 \pm 0.98$ & $\begin{array}{l}3.5-5.3 \\
3.9-7.5\end{array}$ & $5.83 \pm 0.29$ \\
\hline $\begin{array}{l}42 \\
25\end{array}$ & 14 & 84. $9-105.8$ & $98.56 \pm 1.86$ & $6.4-10.7$ & $8.42 \pm 0.39$ \\
\hline 28 & 17 & $89.2-108.2$ & $100.05 \pm 1.33$ & 7. $1-10.8$ & $8.58 \pm 0.28$ \\
\hline $\begin{array}{l}31 \\
34\end{array}$ & $\begin{array}{l}17 \\
16\end{array}$ & $96.4-112.6932 .-115.1$ & $10730+10429+115513$ & 77.1079 .1082 & $850+018096+027$ \\
\hline $\begin{array}{l}34 \\
37\end{array}$ & 11 & $102.2-118.8$ & $11230+1.48$ & $9.6-112$ & $10231-0$ \\
\hline 40 & 9 & $109.3-121.1$ & $112.88 \mathrm{fl} .46$ & $10.7-11.8$ & $11.14+0.12$ \\
\hline 43 & 5 & $113.1-129.3$ & $123.00 \pm 2.85$ & $11.5-12.6$ & $12.18 \pm 0.21$ \\
\hline
\end{tabular}


ous (295 individuals, $62.0 \%$ ) and next in order are insects (93 individuals, $19.5 \%$ ) and frogs (88 individuals, $18.5 \%$ ). The prey fishes were composed of the loaches (Misgurnus anguillicaudatus and M. mizolepis, $83.7 \%$ ), crucian carps (Carassius auratus, 8. $1 \%$ ), green chubs (Aphyocypris chinensis, 5. $8 \%$ ) and unknown small fishes $(2.4 \%)$. The prey frogs consisted of tadpoles $(83.0 \%)$ and adults (17.0 \%) of Rana species, and the prey insects were larvae (83.9\%) and imagoes (1. $1 \%$ ) of the Libelluidae, Iarvae of the Coleoptera (10.7\%) and of the Nepidae $(4.3 \%)$.

The loaches showed a wide range in body length and weight in comparison with the crucian carps and green chubs (Table 3), and went on gradually increasing in size with growth of the chicks (Table 4); that is, the loaches at the 43rd day were 3 times longer and 13 times heavier than those at the 1st day. On the other hand, the individual number of the loaches increased until the 19th clay, but reduced thereafter.

\section{DISCUSSION}

\section{Changes in body weight and relationship of tissue and organ weights to the body weight}

In general, the rates of increase in the body weight in the standing and Rapping phases are much higher than that in the fledging phase in birds (Kuroda, 1959, 1964 a, b; Diamond, 1976; Round and Swann, 1977; Cannings and Threlfall, 1981; Grant, 1982) : this tendency is known also in the Cattle Egret, Bubulcus ibis (Ardeola ibis) (Blaker, 1969), Great White Egret, Egretta alba (Tomlinson, 1976) and Little Blue Heron, Egrettacaerulea [Florida caerulea) (Werschkul, 1979). According to Shiratsuki (1979), the high rate of increase is caused by supplies of nutritious insects before fledging. As for the Eastern Great White Egret, the weight increment was notable until the 37th day after hatching, and the food intake was high up to the 40th day (the end of the flapping phase) (Figs. 1 and 2). The increase of the body weight seen during the period from the 19th to 28th day, however, was less noticeable than that before the above period (Fig. 1). In this connection, the chicks actively wandered short distances until their feet became firm, and Tomlinson (1976) reported a similar behavior from the 15th day in the Great White Egret. The less marked increase of the body weight during the period appears to result from a great expenditure of energy attributable to the standing practice. The relative lipid content in a whole body was highest at the 1st day, and became low with the age in days, but a sudden increase was shown between the 24th and 35th day; this increment indicates the accumulation of lipid (Fig. 2).

From the 20th day onward, nestlings of the Cattle Egret frequently carry out flapping and can fly strongly by the 30th to 35th day as far as $600 \mathrm{~m}$ from the nest (Blaker, 1969). On the other hand, chicks of the Great White Egret begin to fly a short distance at the 40th day and can fly for hunting at the 50th-60th day (Tomlinson, 1976). The first flight of chicks of the Eastern Great White Egret was made at the 40th day, and a great consumption of 
energy for Aapping and flying practices seems to be a reason for the decline of both the body weight and the whole body lipid content during the period from the 37th to 45th clay (Fig. 2). Owing to an increase of food intake due to self-feeding on and after the 50th clay of fledging time, both the body weight and the lipid content in the fledglings gradually increase and appear to approximate to those in the adults.

The body weight and whole body lipid content in the adults fluctuated remarkably at times of migration and breeding activity (Fig. 2) ; that is, it seems that both the body weight and the lipid content in the adults decreased by a marked consumption of energy for migration in April (the advertising phase) but recovered from the loss by active feeding in May; the reduction of food intake due to brooding and breeding in the adults, however, led to a decrease of the body weight in June; in August the body weight increased with the accumulation of lipid needed for energy of migration.

As for the relationship of the tissue and organ weights to the body weight (Fig. 3), the growth rates of the pectoral muscle, whole bones and feathers were rapid, compared with those of the skin and the others (viscera) which occupied high percentages immediately after hatching. Especially, the copious growth of the pectoral muscle and whole bones after the 35th day may be closely associated with flapping and flying practices.

\section{Changes in food habit of the chicks}

The parent egrets regurgitate partly digested food on to the center of the nest and chicks then feed directly off the nest. The chicks feed on animals such as mammals, reptiles, crustaceans, mollusks and annelids (Kim, 1969 ; Won, 1981), fishes, frogs and insects (this paper). Such a variety of prey seems to be caused by differences in the habitat. For example, the egrets staying in seashore prey sea fishes or shrimp (Ikeda, 1956; Kim, 1969), while the egrets in paddy fields, rivers and fresh water marshes capture fresh water fish, crustaceans, frogs and insects (Kosugi, 1960). The present study area was situated in inland, thus the prey consisted of fresh water species (Table 2).

Of the prey fishes, the loaches were numerous in number compared with crucian carps and green chubs. The fact suggests that it is more difficult for the adult egret to hunt the swimming crucian carps and green chubs which move into rivers and fresh water marshes after spawning in the rice field, than the benthonic loaches. On the other hand, fishes were eaten everyday from 1 June to 13 July, but the frogs and insects only during the periods from 7 June to 28 and 19 June, respectively, corresponding to the periods of their highest population density (Ishida, 1969; Nakamura and Ueno, 1970; Hasegawa, 1973; Kawada, 1959). The size of the loaches increased as the chicks grew (Table 4). Judging from their feeding mode, it is pointed out that the chicks have chances of food choice; accordingly, the size increment of the loaches accompanied with growth of chicks suggests that the more the chicks grow, the larger fishes they select.

From this study, it is revealed that the egret feeds on the fresh water 
fishes, frogs and useful insects for agriculture. However, no data have been presented to show that populations of such prey animals are limited by egret predation. The egret is regarded as a beneficial bird, because the bird preys on such pest animals for agriculture as crawfishes and rats (Ikeda, 1956; Kosugi, 1960; Won, 1981). In consequence, we emphasize the conservation of the Eastern Great White Egret as a useful bird.

\section{ACKNOWLEDGEMENTS}

We wish to thank Professor T. A. Uchida, Zoological Laboratory, Kyushu University and Professor E. W. Jameson Jr., University of California for comments on the manuscript, and Professor P. 0. Won, Kyung Hee University for his valuable advices. We are indebted also to Associate Professor S. Kimura, Laboratory of Fisheries Environmental Science, Kyushu University for identification of the prey fishes, Mr. D. P. Lee, the Korean Association for Conservation of Nature, Inc. for his kind helps and Dr. T. Mōri, Zoological Laboratory, Kyushu University for his assistances.

\section{REFERENCES}

Blaker, D. 1969 Behaviour of the Cattle Egret Ardeola ibis. Ostrich, 40: 75-129

Burger, J. 1978 Competition between Cattle Egrets and native North American herons, egrets, and ibises. Condor, 80: 15-23

Cannings, R. J. and W. Threlfall 1981 Horned Lark breeding biology at Cape ST. Mary's, Newfoundland. Wilson Bull., $93: 519-530$

Diamond, A. W. 1976 Subannual breeding and moult cycles in the Bridled Tern Sterna anaethetus in the Seychelles. Ibis, 118: 414-419

Faber, R. A., R. W. Risebrough and H. M. Pratt 1972 Organochlorines and mercury in Common Egrets and Great Blue Herons. Environ. Pollut., (3) : 111-122

Grant, P. R. 1982 Variation in the size and shape of Darwin's finch eggs. Auk, 99: 15-23

Hancock, J. and H. Elliott 1978 Great White Egret. In "The Herons of the World," New York, Harper and Row, pp. 232-235

Hasegawa, H. 1973 Water Scorpion, In “Animal Life," Vol. 12, Japan Mail Order, pp. 21932194 (in Japanese)

Honda, K., R. Tatsukawa and 'T. Fujiyama 1982 Distribution characteristics of heavy metals in the organs and tissues of striped dolphin, Stenella coeruleoalba. Agric.Biol.Chem., $46: 3011-3021$

Honda, K., R, Tatsukawa, K. Itano, N. Miyazaki and 'T. Fujiyama 1983 Heavy metal concentrations in muscle, liver and kidney tissue of striped dolphin, Stenella coeruleoalba, and their variations with body length, weight, age and sex. Agric. Biol.Chem., 47: 1219-1228

Ikeda, S. 1956 On the food habits of Japanese birds. Ornithological and Mammalogical Report, (15) : 52-65 (in Japanese)

Ishida,S.1969 Insects' Life in Japan. Vol. 2, Dragonflies. Hoikusha Publishing Co., Ltd., Osaka (in Japanese)

Kawada, A. 1959 Illustrated Insect Larvae of Japan. Hokuryukan Co., Ltd., Tokyo (in Japanese)

Kim, H.K.1969 Biology of Gray Heron and egrets. J.K. R. Z. B. K., 2: 69-81 (in Korean 
with English summary)

Koeman, J. H., Th.Bothof, R. de Vries, H. van Velzen-Blad and J. G. Vos 1972 The impact of persistent pollutants on piscivorous and molluscivorous birds. TNO-nieuws, 27: 561-569

Kosugi, A. 1960 On the food habits of some herons. Misc. Rep. Yam. Inst., 4: 91-105 (in Japanese with English resume)

Kuroda, N. 1959 Field studies on the Grey Starling Sturnus cineraceus Temminck. 2. Breeding biology (part 3). Misc. Rep. Yam. Inst., 13: 535-552 (in Japanese with English summary)

Kuroda, N. 1964 a Data on body weight, fat weight and gonad size of lighthouse struck and other birds. Misc. Rep. Yam. Inst., 4: 71-75 (in Japanese with English summary)

Kuroda, N. 1964 b Analysis of variation by sex, age and season of body weight, fat and some body part in the 'Tusky Thrush, wintering in Japan. Misc. Rep. Yam. Inst., 4: 9195

Low, G. and W. Manse11 1983 Great Egret. In "North American Marsh Birds," New York, Harper and Row, pp. 37-39

McClure, H. E. 1974 Migration and Survival of the Birds of Asia. Appl. Sci. Res. Corporation of Thai., Bangkok

Nakamura, K. and S. I. Ueno 1970 Japanese Reptiles and Amphibians in Color. Hoikusha Publishing Co., Ltd., Osaka (in Japanese)

Pratt, 1-I. M. 1970 Breeding biology of Great Blue Herons and Common Egrets in central California. Condor, 72: 407-416

Prestt, I. 1969 Organochlorine pollution of rivers and the heron (Ardea cinerea L.). Pap. Proc. Tech. Meet. int. Un.Conserv. Nat. nat. Resour., llth, 1: 95-102

Round, I'. D. and R. L. Swann 1977 Aspects of the breeding of Cory's Shearwater Calonectris diomedea in Crete. Ibis, 119: 350-353

Shiratsuli, N. 1979 About pigeons -Classification and ecology. Report of Nara-mycin Research Association: Comfortable Environments, (4) : 2-9 (in Japanese)

Seong, K. E. 1979 Ecology of egrets and a heron. The Conservation of Nature, (5) : 59-64 (in Korean)

'lanabe, S., R. Tatsukawa, K. Maruyama and N. Miyazaki 1982 Transplacental transfer of PCBs and chlorinated hydrocarbon pesticides from the pregnant striped dolphin (Stenella coeruleoalba) to her fetus. Agric. Biol. Chem., 46: 1249-1254

Tanabe, S., R. Tatsukawa, H. Tanaka, K. Maruyama, N. Miyazaki and T. Fujiyama 1981 Distribution and total burdens of chlorinated hydrocarbons in bodies of striped dolphin (Stenella coeruleoalba). Agric. Biol. Chem., 45 : 2569-2578

Tomlinson, D. N. S. 1976 Breeding behaviour of the Great White Egret. Ostrich, 47: 85-94

van der Molen, E. J., A. A. Blok and G. J. de Graaf 1982 Winter starvation and mercury intoxication in Grey Herons (Ardea cinerea) in the Netherlands. Ardea, 70: 173-184

Werschkul, D. F. 1979 Nestling mortality and the adaptive significance of early locomotion in the Little Blue Heron. Auk, 96: 116-130

Won, P. 0. 1975 Bird Treasures (Natural Monuments) in Korea. Member, Culture Property Preservation Committee, Ministry of Culture and Information, Seoul (in Korean)

Won, P. 0. 1981 Illustrated Flora and Fauna of Korea. Vol. 25, Avifauna. Ministry of Education, Seoul (in Korean) 